\title{
ノア画像を用いた大興安嶺地区山火事の回復に関する研究
}

\section{A Study on Recovery of Forest Fire in Da Xing An Ling Using NOAA Imagery}

\author{
劉会傑*，本多 嘉明* \\ 村井 俊治*, 小井土今朝已** \\ Liu Hui JIE*, Yoshiaki HONDA* \\ Shunii MURAI*, Kesaaki KOIDO**
}

\begin{abstract}
In May 1987, the china-USSR border area along the Amur River, so called Da Xing An Ling District, Hei Long Jiang Province was damaged by a very big forest fire which covered about 10,000 square kilometers.

Chinese LANDSAT Receiving Station has succeeded to take three TM images just after the fire in May and June 1987.

NOAA Receiving Station at the Institute of Industrial Science, University of Tokyo has also succeeded to take two cloud free scenes in July 1987 just after the fire and in September 1988 a year after the fire.

The objective of this study is to evaluate the recovery of the forest fire using NOAA imagery.

Normalized Vegetation Index (NVI) was utilized to classify the forest damage and its recovery after a year.

The result of the study showed that 95 per cent of total damage area of 9,778 square kilometers in Da Xing An Ling District was recovered in vegetation without trees but grasses after a year.
\end{abstract}

概 要：1987年 4 月に中国とソ連の国境となっている黒龍江（アムール河）をはさんで，大規模な山林火災が起きた。 中国の人民日報によると中国側だけで1987年 5 月から約一力月間燃えつづけ, 東西幅約 $220 \mathrm{~km}$, 南北約 $90 \mathrm{~km} の$ 範囲が燃之 た。面積で言えば関東平野より広大な面積が燃えたことになる。

火災直後には LANDSAT TM が大興安嶺の一部を把之, 中国科学院遥感衛星地面站は 25 万分の 1 縮尺の画像図「大興 安嶺林火地区衛星影像平面図」を出版した。

東京大学生産技術研究所の NOAA の受信局は，山火事が鎮火した1987年 7 月 6 日に中国側被災地を比較的少ない雲量 の画像として取得した。また，ほぼ一年後の1988年 9 月25日の NOAAの画像も山火事地域を把えている。

山火事の生じた大興安嶺地区は中国において唯一の原生林地域であり，その森林資源の保護はきわめて重要な意味を有 する。

このような背景から, 本論文は, NOAA 画像のグローバルな監視能力に着目し, 大興安嶺地区を調査区域として, 山火 事の被害状況，一年後の植生回復状況等を定量的に把握することを目的とする。

* 東京大学 生産技術研究所

$* *$ 建設省 国土地理院

* Institute of Industrial Science, University of Tokyo

* Geographic Survey Institute, Ministry of Construction

「写真測量とリモートセンシング」Vol.28, No. 4, 1989

\section{1. 調查区域}

図 1 は，中国の地図出版社が発行している中華人民 共和国地図集から取ったもので黒龍江省大興安嶺地区 を示している。大興安嶺地区は中ソ国境となっている 黑龍江の南側に位置し, 北緯 $50^{\circ}$ から $54^{\circ}$ まで, 東経 $121^{\circ}$ 


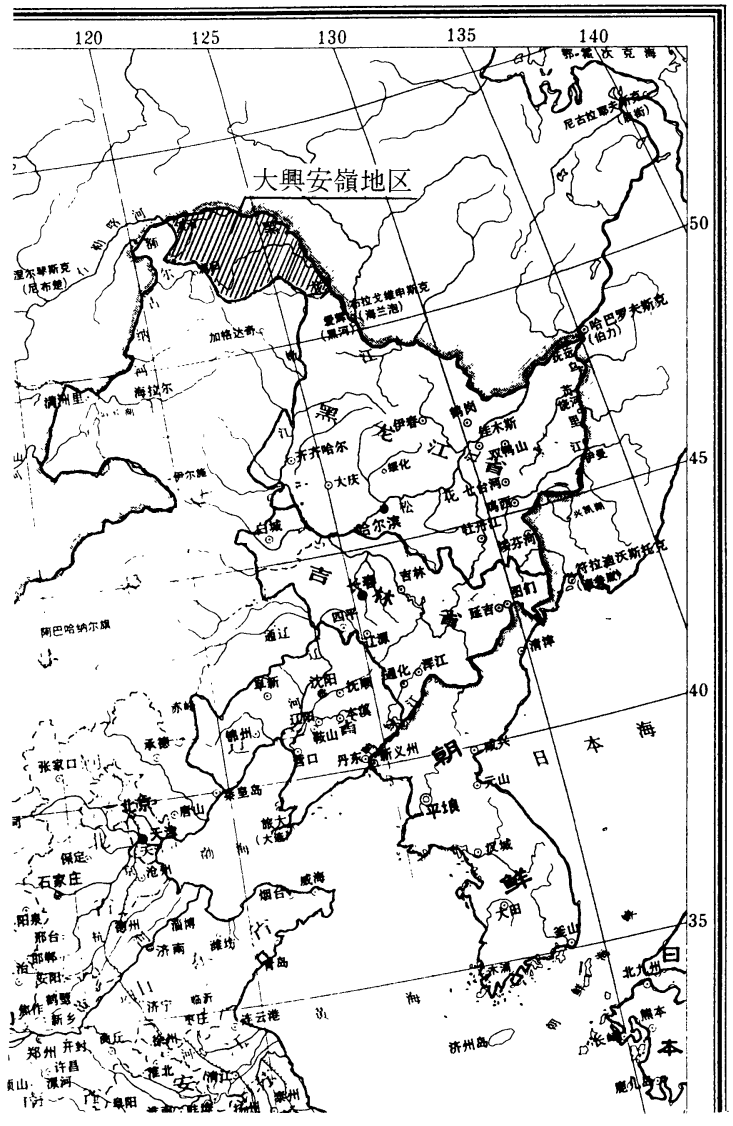

図 1 調査区域 黒龍江省大興安嶺地区

から $128^{\circ}$ までの地域で約 $60,000 \mathrm{~km}^{2}$ の面積である。同 地域の標高は $600 \mathrm{~m} \sim 1,500 \mathrm{~m}$ の比較的平坦な林野と, なだらかな丘陵で構成され，ダフリアカラマツ，コウ アンシラカンバ, シベリアアカマツ, チョウセンヤマ ナラシ等の原生林で覆われている。Köppenの気候区 分によれば，同地区は亜寒帯気候と大陸性混合林気候 の境界にあり，寒冷時には大気が乾燥し山林火災の頻 度の高い地区でもある。米軍が発行している100万分の 1 の航空図 (ONC) によって, この地域は河川および 山岳以外は殆ど緑一色で塗られ森林で覆われているこ とがわかる。

\section{2. 利用できる NOAA 画像}

大興安嶺地区は毎年10月から 5 月近くまで雪水に覆 われるため, 植生分布を見るには 7 月から 9 月末まで の NOAA 画像が適している。

山林火災の生じた面積が広大なため上記の期間で雲
量の少ない NOAA 画像はきわめて少なく, 雲量の少 ない画像の探索に膨大な作業を要した。

結局, 次の 2 シーンを良好な NOAA 画像として選 定した。
(1) 1987 年 7 月 6 日 午前 6 時 42 分
(2) 1988年 9 月 25 日 午前 8 時43分

図 2 は中国の LANDSAT 受信局が取得した1987年 5 月 $23 \cdot 30$ 日および 6 月 6 日の TM モザイク画像であ $\eta$, 大興安嶺地区の一部である。この LANDSAT TM 画像は 25 万分の 1 縮尺で作られており, 山火事により 森林が完全に焼けたかどうか被災状況のグランド ・ トゥルースの代替として用いられた。

なお, 出火時の NOAA 画像については科学朝日 1987年 8 月号の燃える中り国境 (斉藤誠一, 清水雅男) を参照した。

\section{3. 山火事調査のための画像処理}

\section{1 幾 何補 正}

大興安嶺地区は, NOAA 画像のほぼ中央に位置して おり, 画像の巾 $3,000 \mathrm{~km}$ のち約 $1 / 5$ の巾のなかに入 るため, システム補正は行なわず, 前述の米軍発行の 航空図 (ONC) に基準点を求め，2次の多項式による 幾何補正を行なった。1987年のシーンは11点，1988年 のシーンは 8 点の基準点を用い, それぞれ幾何補正の 精度は土0.91画素, \pm 1.13 画素であった。

大興安嶺地区の行政界は, 300万分の 1 の地図 (中華 人民共和国地図集）からディジ夕イザーで読み取り， NOAA 画像の中に書き入れた。また, 前述の「大興安 嶺林火地区衛星影像平面困」 から中国側の山火事被災 地域の輪郭をもディジタイザーで読み取り, NOAA 画 像の中に描き入れた。

図 3 および四 4 は, 前述 2 時期の NOAA 画像の幾 何補正済面像である。困 3 の黒い斑状のところが山火 事である。困 4 では山火事跡は殆どわからない。

\section{2 スペクトル分類}

NOAAのAVHRR (Advanced Very High Resolution Radiometer)のバンド構成は表 1 に示すとおりで ある。被災地については, 図 2 の LANDSAT TM 画 像を参考に被災強度大・小のグランド・トゥルース・ デー夕を抽出するため, 被災強度図（四 5 参照）を作 成した。四 6 は，2 時期における 5 つのバンドに対す 
表 1 NOAA AVHRR バンド構成

\begin{tabular}{|c|c|c|c|}
\hline バンド & $\begin{array}{c}\text { 波長帯域 } \\
(\mu \mathrm{m})\end{array}$ & $\begin{array}{c}\text { 分 解 能 } \\
(\mathrm{km})\end{array}$ & 観測対象 \\
\hline 1 & $0.58 \sim 0.68$ & 1.1 & 雪水分布, 濁水分布 \\
\hline 2 & $0.73 \sim 1.10$ & 1.1 & 水陸境界, 植生分布 \\
\hline 3 & $3.55 \sim 3.93$ & 1.1 & 夜間における温度分布 \\
\hline 4 & $10.5 \sim 11.5$ & 1.1 & 温度分布 \\
\hline 5 & $11.5 \sim 12.5$ & 1.1 & 温度分布 \\
\hline
\end{tabular}

る原生林, 山火事跡, 川, 雲の平均值, $\pm 1 \sigma$ （ $\sigma$ は標 準偏差）值を示したものである。次式で表される正規 化植生指標 (Normalized Vegetation Index : NVI) を算出し，その特性を第 1 バンドおよび第 2 バンドの 分光特性と比較できるように図 6 の中に並べてある。 ただし，処理した1988年の NOAA 画像には雲が存在 しなかった。

$$
\mathrm{NVI}=\frac{\text { 第 } 2 \text { バンドー第 } 1 \text { バンド }}{\text { 第 } 2 \text { バンド十第 } 1 \text { バンド }}
$$

以上に示したスペクトル特性から次の事が言える。

（1）山火事跡は，図6 からわかるように山火事直 後の NOAA 画像 (1987年)の第 2 バンドで原生 林と明瞭に判別できる。

(2) 図 6 からわかるようにNVIにおいても，山 火事直後の NOAA 画像 (1987年) では山火事跡 を原生林と明瞭に判別できる。NVIの方が第 2 バンドより山火事跡を判別するのにより有効で あった。

（3）山火事跡に着目すると，NVI 值から被災強度 が大小の 2 段階に分類できる。本研究では図 6 一(3)からわかるように NVIが0.2以下を被災 強度大とし, NVI が0.2〜0.4を被災強度小とし た。

（4）雲は，その他の原生林，山火事跡，川と第 1, 2，4，5 バンドおよびNVIによって明瞭に区 別できる。第 4 および第 5 バンドがより確実に 雲を判別できた。

図 7 は, NOAA 画像の NVI から作成した山火事被 災図である。なお，雲の影は，第 4 および第 5 バンド で低い值を示し，これを除去することができる。雲お よび雲の影は第 4 バンドを用いて処理を行なった。

\section{3 山火事跡の植生回復調査のためのスペクトル} 処理

1987年 7 月と 1988年 9 月の画像では，それぞれ取得 された月および時刻が異なるので，単純にNVIの值 を比較することが出来ない。これを考慮した上で，2 時期の山火事跡の NVI を原生林の NVIの平均值で 割って基準化した值を用いた。すなわち，縦軸は1988 年の NVIの值をその年の原生林の NVIの平均值で 割った值，横軸は1987年の NVIの値をその年の原生 林の NVIの平均值で割った值としてNVI 比の散布 困を作成し，図８に示した。この図において傾き1の 直線よりも上にあるものは植生が回復したと考えられ る。これに基づき山火事跡の植生回復の状況を示した ものが図 9 である。

以上の図から次のことが指摘できる。

（1）散布図および山火事跡植生回復状況図から見て 植生回復が認められるところと，回復が一年後に おいても進んでいないところが認められる。

（2）先に作成した山火事被災図（図 7 参照）と比較 すると，被災強度の大小に関わらず，植生回復の 状況は全般的に進んでいることがわかる。NOAA 画像から得られた被災強度別の面積および植生回 復部の面積を表 2 に示す。

\section{GLOBAL VEGETATION INDEX による植生回復の判定について}

\section{1 大興安嶺地区山火事跡における植生の時系列 变化}

NOAA の AVHRRによる1987年 7 月と 1988年 9 月 の 2 時期の画像からだけでは，山火事の被害がどのよ うに回復したのか時系列的な変化がわからない。そこ で，グローバルな監視力と時系列データとして扱える GLOBAL VEGATATION INDEX データに着目し, 時系列変化として大興安嶺地区山火事跡における植生 回復の観測をする。

\subsection{GLOBAL VEGETATION INDEX について}

NOAA / NESDIS は, 1982年 4 月以降, NOAA 衛星 のAVHRRの第 1 バンドと第 2 バンドを用いて正規 化植生指標を計算し，毎日の正規化植生指標画像 (AVHRR-GAC デー夕, 解像度 $4 \mathrm{~km}$ ) を合成してい る。本研究で用いた GLOBAL VEGETATION 

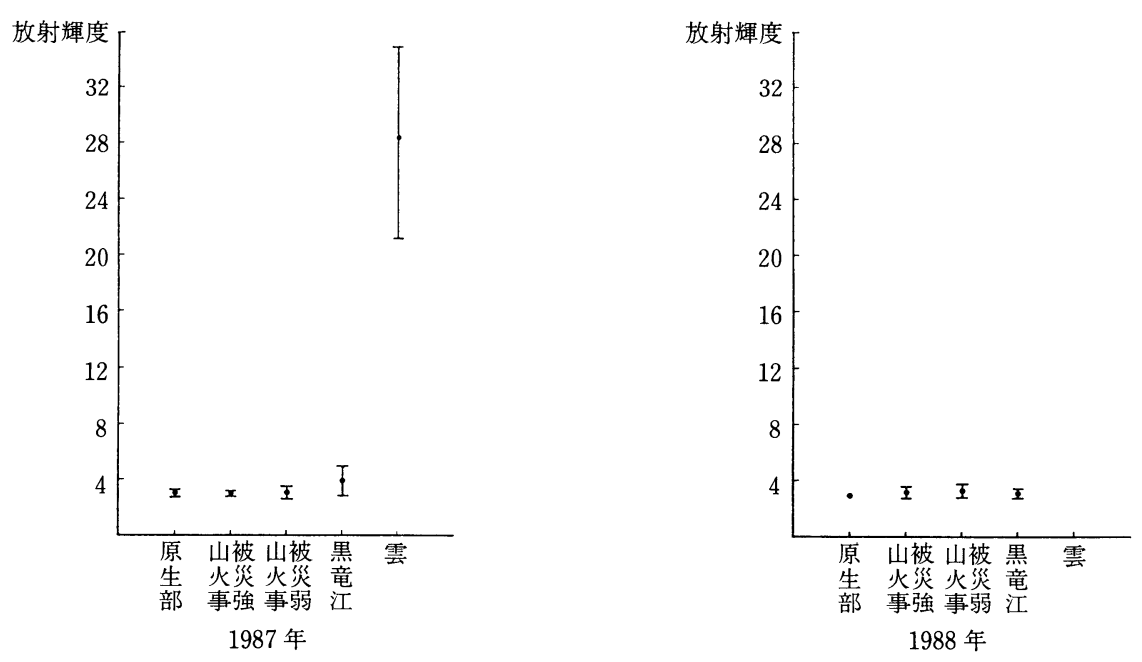

（1）第 1 バンドの特性
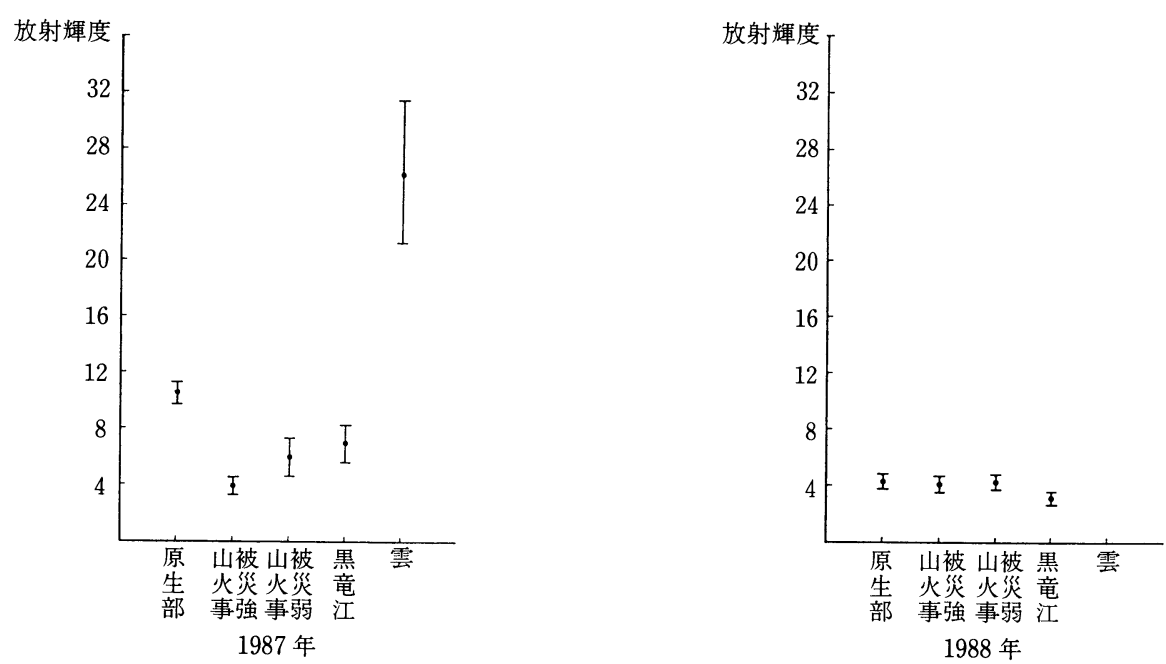

(2) 第 2 バンドの特性
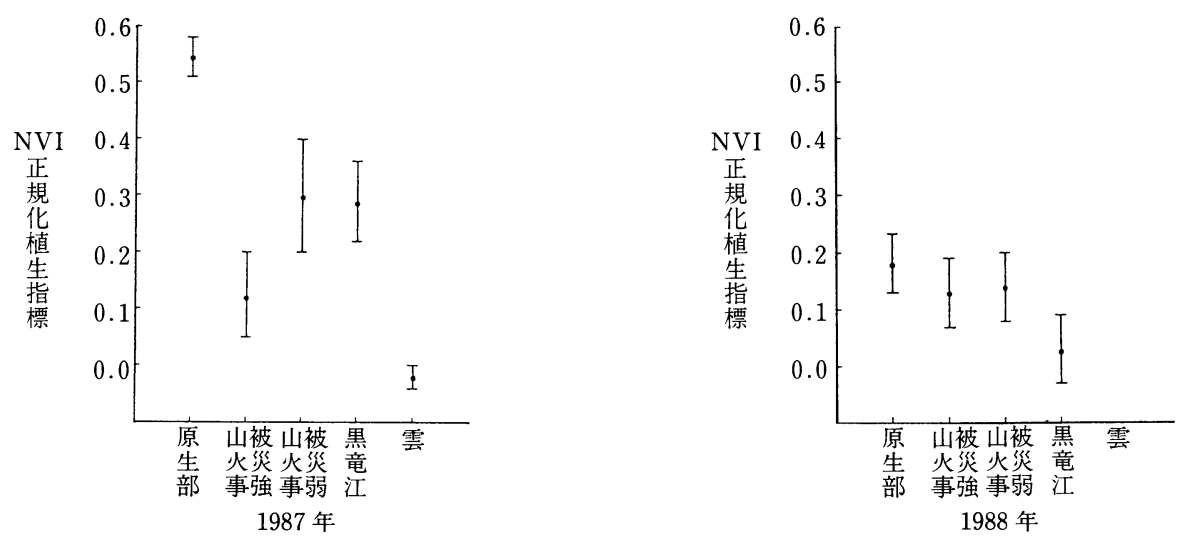

（3）正規化植生指標(NVI)の特性

図 6 厚生林, 山火事跡, 黒龍江, 雲のスペクトル特性 
輝度温度

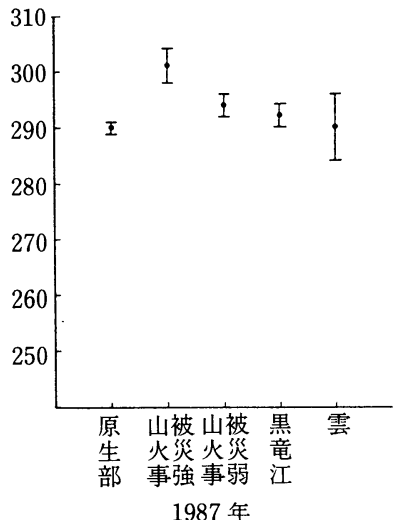

輝度温度

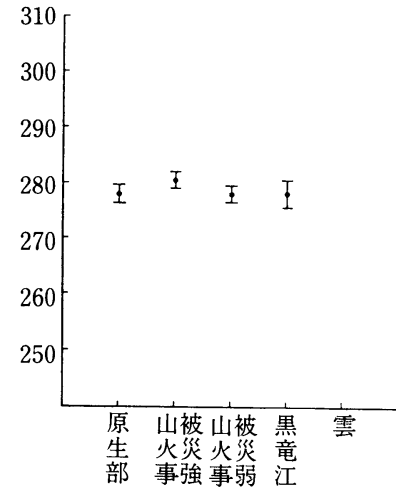

1988 年

（4）第 3 バンドの特性

輝度温度

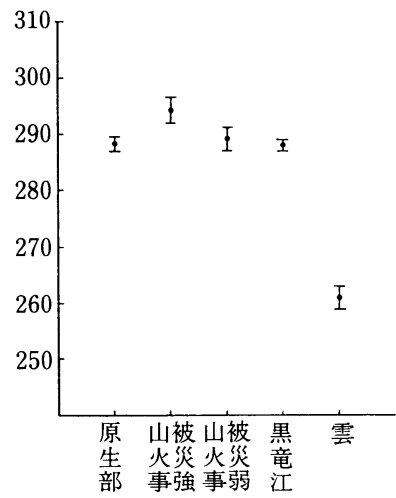

1987 年

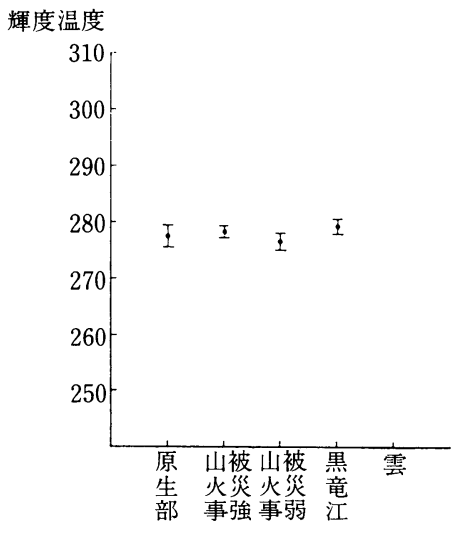

1988 年

（5）第 4 バンドの特性

輝度温度

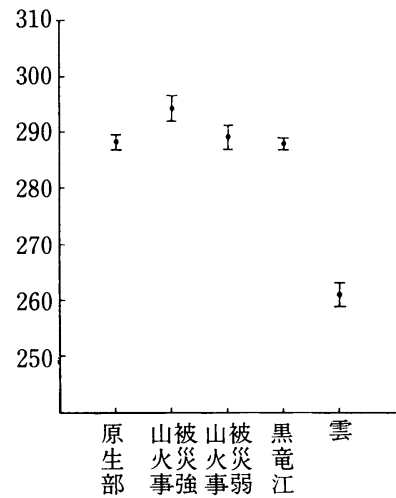

1987 年
輝度温度

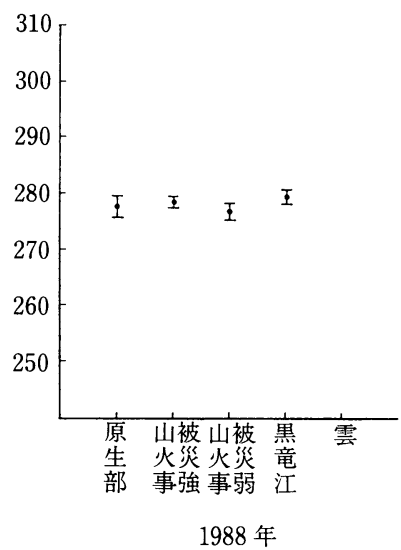

1988 年

（6）第 5 パンドの特性

図 6 厚生林, 山火事跡, 黒龍江, 雲のスペクトル特性 (つづき) 
表 2 山火事被災および回復状況

\begin{tabular}{|c|c|c|c|c|c|c|}
\hline \multicolumn{2}{|r|}{ 地 } & 域 & \multicolumn{2}{|c|}{ 大興安嶺地区 } & \multicolumn{2}{|c|}{ 画 面 全 体 } \\
\hline \multirow{4}{*}{$\begin{array}{l}\text { 山 } \\
\text { 火 } \\
\text { 事 }\end{array}$} & 被災強度 & NVI & 被災面積 (1987) & 被災面積 (1988) & 被災面積 (1987) & 被災面積 (1988) \\
\hline & 大 & 0.2 未満 & 5,221 & 5,065 & 6,157 & 5,841 \\
\hline & 小 & $0.2-0.4$ & 4,557 & 4,178 & 8,158 & 6,881 \\
\hline & 合 & 計 & 9,778 & 9,243 & 14,315 & 12,722 \\
\hline
\end{tabular}

単位: $\mathrm{km}^{2}$

INDEX データ(以下, GVI データと呼ぶ。)は上のデー 夕から一週間ごとにNVIの最大值を求めポーラ・ス テレオの形で作られた正規化植生指標画像（解像度 $15 \sim 30 \mathrm{~km})$ のとである。ここで用いたデー夕は次の とおり 3 つの連続したデータである。

\section{調査データ}

（1）山火事の被害を受けていない年 1986年 5 月上旬 $\sim 9$ 月下旬

(2) 山火事が発生した年 1987年 5 月上旬 9 月下旬

（3）山火事があった翌年

1988年 5 月上旬 $~ 9$ 月下旬

\section{3 山火事後の植生回復調査}

\section{3 .1 山火事跡の特定}

山火事の被害が最导強かった部分を通る緯線（北緯 $\left.52^{\circ} 56^{\circ} 22^{\prime \prime}\right)$ 上の NVIの変化を調べれば, 山火事の被害 および回復の状況を観測できる。1986年, 1987年, 1988 年のそれぞれに対して，5月上旬， 6 月中旬， 9 月下 旬の 3 時期について NVI を縦軸にとり前述の緯線上 の NVIの断面を示したものが図10である。これらの グラフより次のことがわかる。なお， 7 月および 8 月 については，雲などの天候の影響を受けているため NVIの值が不安定になりグラフ化し比較するには不 適当である。

（1） 5 月上旬と 9 月下旬の NVI 断面を見ると 3 年 とも大きな差異がない。

（2）6月中旬の NVIの断面に着目すると，大きな 差異が生じているところがある。1986年の NVI 断面は比較的平坦であるのに対して，1987年では ピクセルNo. 32から47に対応しているNVIの值 が低く，そこが山火事であることを示している。

（3） 1988年の山火事跡では, NVIの值が1987年ほど ではないが周囲に対して低い值を示しており，植

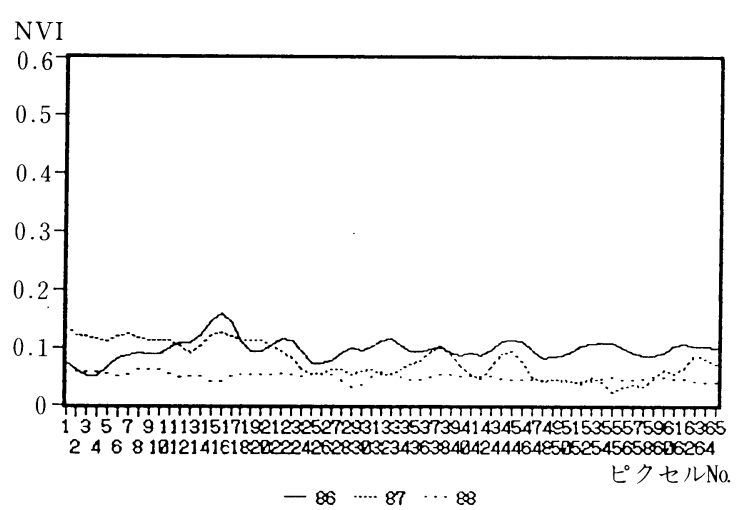

(a) 5 月上旬の NVI 断面
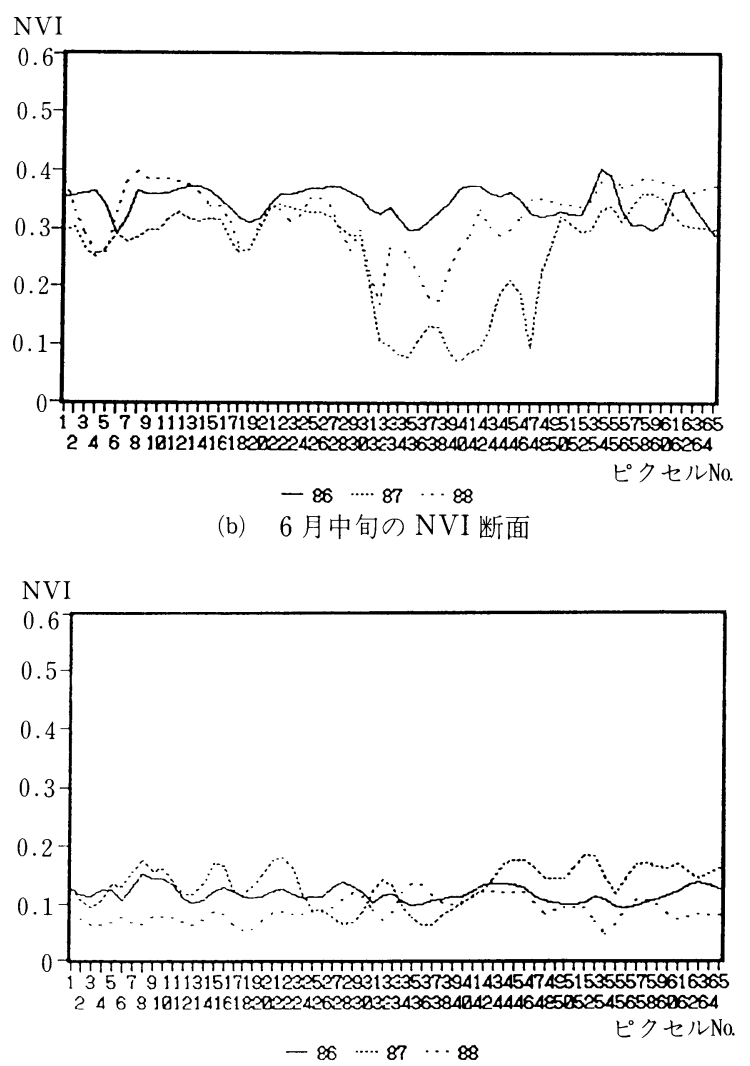

(c) 9 月下旬の NVI 断面

図10 NVI 断面 

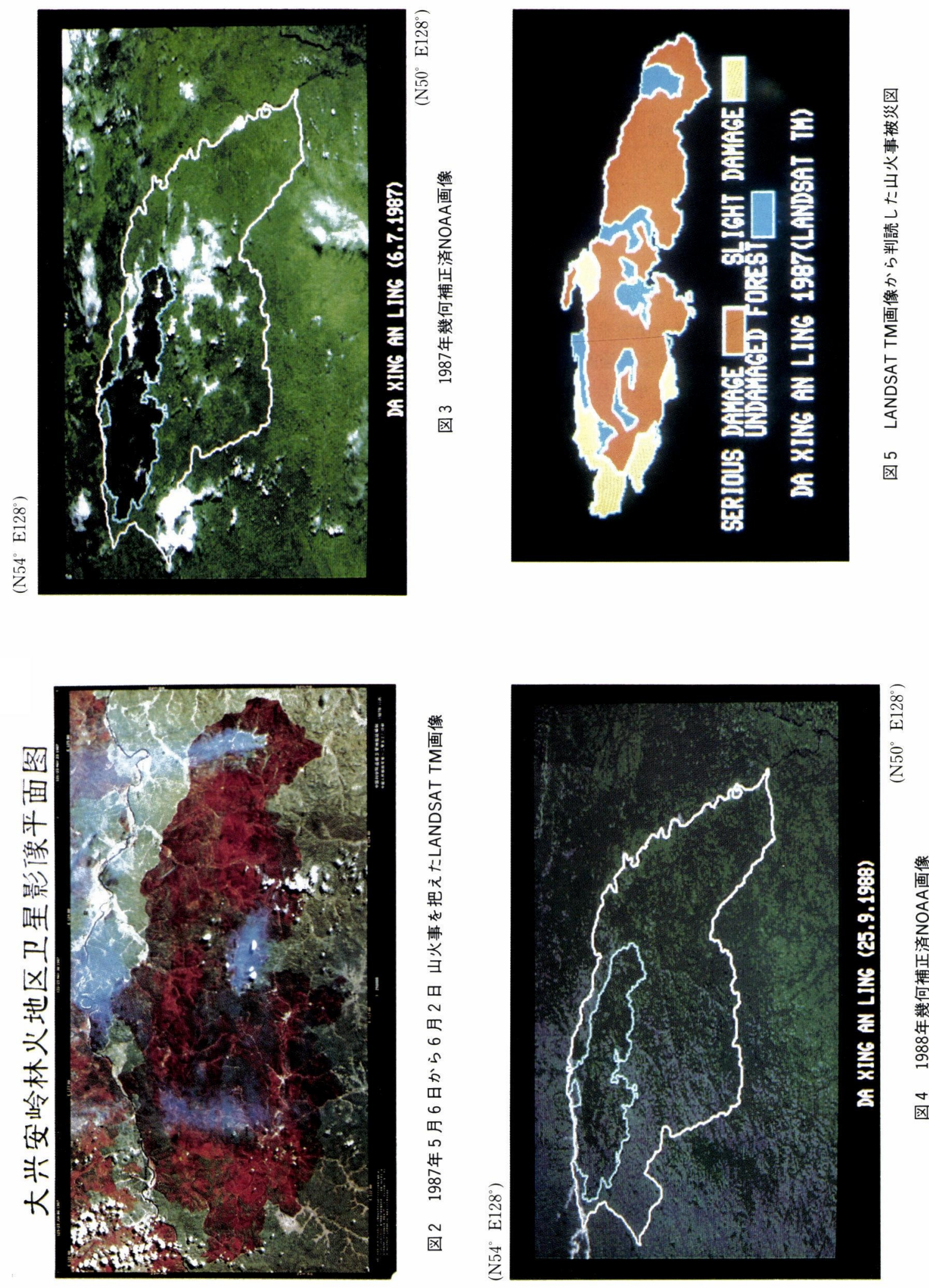

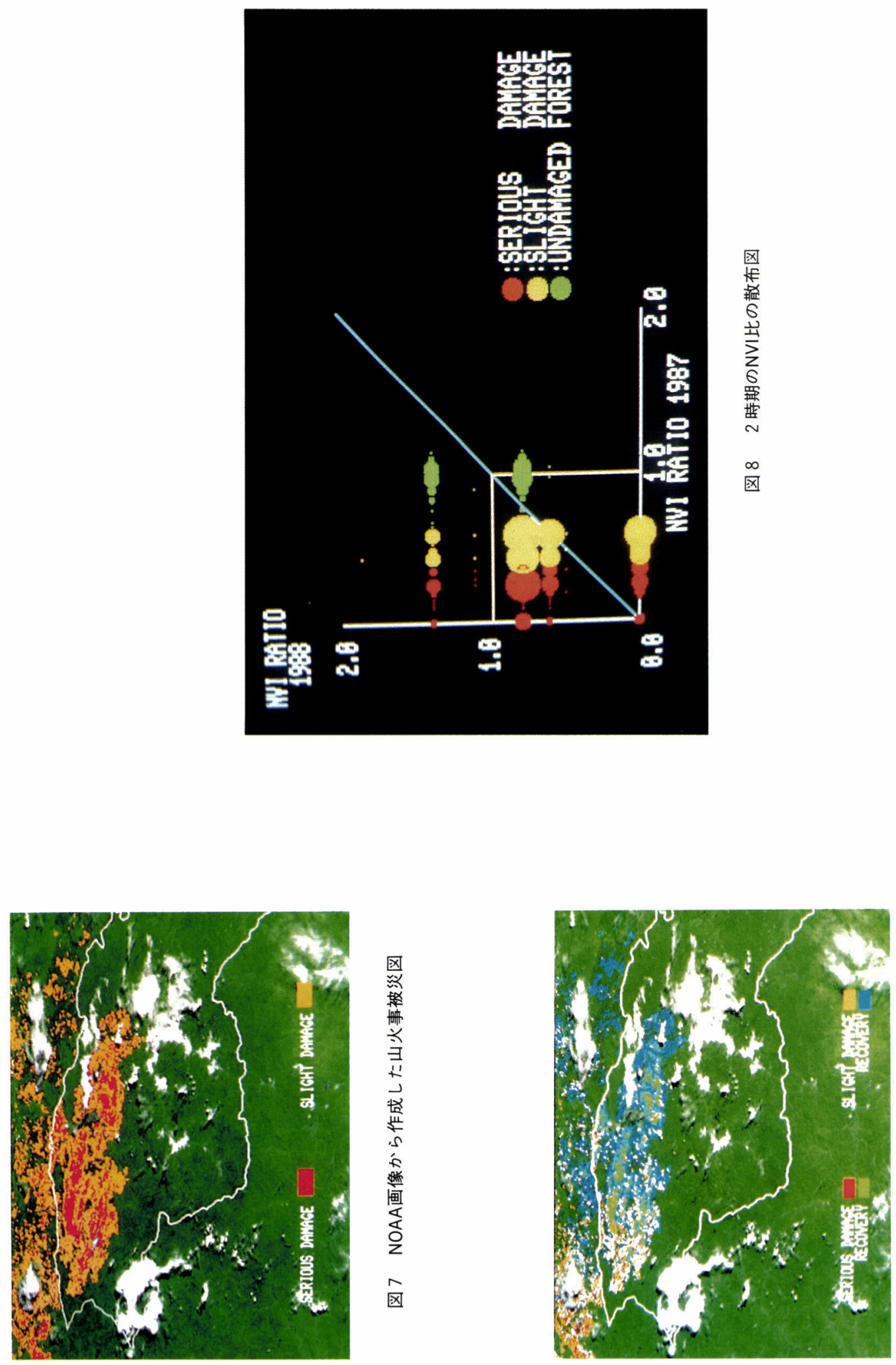
生が回復しているものの完全には回復していない

ことを示している。

\subsection{2 山火事跡および森林の NVI 時系列変化}

図10より，典型的な山火事跡および森林のピクセル としてそれぞれピクセル No. 36および56を選び， 5 月 上旬から 9 月下旬までの NVIの時系列変化を 4 週間 ごとの最大值で示したものが図11である。困11から次 のことが言える。

（1）森林では, NVIの時系列変化が1986年, 1987年, 1988年の 3 年間の間でほとんど差異がない。

（2）山火事跡では, NVIの時系列変化が1987年が一 番低く，1988年が1986年と1987年の間に位置して おり，山火事跡での植生の回復がうかがえる。

山火事の翌年に植生が回復していることから山火事 跡の遷移系列は 2 次遷移であり, その回復は草本類が 中心と考えられる。また，被災一年後である1988年に 現地調査に参加した北海道大学農学部の長谷川栄博士 によれば，林床の草本類は殆ど回復しているが，枯死

\section{N V I}

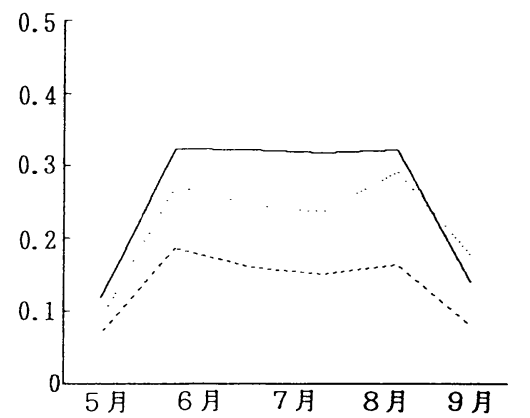

一 1986年

‥-1987年

…. 1988年

(a) 山火事跡の NVI 時系列変化 ( 4 週目の最大值による)

N V I

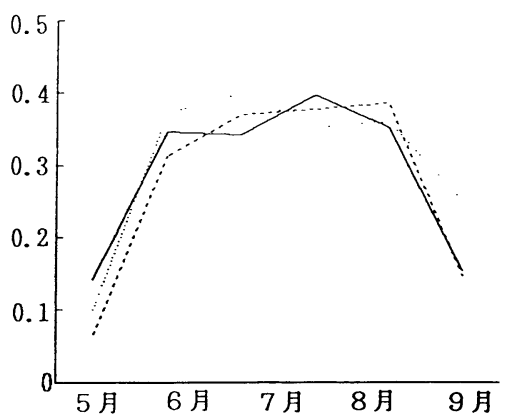

(b) 森林の NVI 時系列変化 (4 週目の最大値による)

図11 NVI 時系列変化
- 1986年 1987年 1988年

焼木は立ったままであったという。

なお， 5 月上旬と 9 月下旬で NVIの值が低いため, 植生分布の観測は適当でないと考えられる。これは, 草本類および木本類の葉が枯れているためと考えられ る。

\section{NOAA 画像および GVI データ から得られた知見}

まず，NOAA 画像から次のことが指摘できる。

（1）数 $100 \mathrm{~km}$ におよぶ広大な山林火災の被災面積を 同日時の NOAA 画像で把握することが出来た。黒 龍江省大興安嶺地区で $9,778 \mathrm{~km}^{2} の$ 被災面積が確認 できた。

（2）正規化植生指標により被災の強度を 2 段階に分類 することが出来た。

（3）黒龍江省大興安嶺地区における被災面積は, 9,778 $\mathrm{km}^{2}$ であったが，一年後において植生が回復してい ると見られる面積が $9,243 \mathrm{~km}^{2}$ ることがわかった。

(4) 広大な山火事の被災状況および回復状況を監視す るのに, NOAA 画像を用いた正規化植生指標の利用 が有効であることが明らかとなった。

次に, GVI データから次のことが指摘できる。

(1) GVI データで大興安嶺地区山火事跡が確認でき た。

（2）1988年では大興安嶺地区山火事跡の植生回復が確 認できた。これはおもに林床の草本類によるものと 考えられる。

（3）大興安嶺地区の植生分布を観測するには，7月か ら8月の間で雲などの天候の影響を受けない時期が 適している。

\section{参 考 文 献}

1）人民日報：1987年 5 月 $13 \cdot 14$ 日

2 ) 地図出版社 中華人民共和国地図集：1979年

3 ) 中国科学院遙感衛星地面站 大興安顗林火地区衛星影 像平面図：1987年11月

4) 燃える中ソ国境：斉藤誠一, 清水雅男, 科学朝日 1987 年 8 月号

5 ) 中国大興安領の森林火災の判読：渡会敏明, 長谷川栄, リモートセンシング研究セミナー資料，1989年 1 月27日

6) GLOBAL VEGETATION INDEX USERS' GUIDE : Satellite Data Services Division, U.S. Department of Commerce, MAY 1986 